た上で,それでも明らかにならない場合には針生検を， 最終的には頸部腫瘤からの生検を考慮する。質問 村上 泰(京府医大). T1，2 で頸転移巣が大きいもの ては，何か腫瘍学的特性に差があると思われる。 そこ で, 原発巣の処理が大切だ. 照射化学療法では再発す
るのが多い.どうしているか. 応答 1 ) 小さな 原発病栄に対しては, 上咽頭癌では放射線治療にて, 中, 下咽頭癌に対して壮手術にて比較的上く制御され ていた．2）早期に頸部転移をきたした症例の，腫場 生物学的な特性については今回唡討していない。

\title{
63. 当教室における咽頭癌剖検例の検討
}

\author{
河合 敏・湯山誠一郎・佐藤博久 古川 滋・持松いづみ・澤木修二（横浜市大） \\ 佃守（神奈川県立がんセンター）
}

目的 咽頭の覀性腫漡は上咽頭，中咽頭，下咽頭で 治療法が若干異なるが，予後はいずれも不良である。 われわれは1980年89年までの10年間に，当科において 咽暊の癌で死亡し，剖検を行った38例（上記の部位別 に17，11，10例)について死亡原因を中心に検討した。

結果 病理組織は全例屏平上皮癌で, その分化度は 全般に低分化型が多かった. 初診時ステージ分類では, 各咽瑱癌ともステージIVの進行例が多かった。剖娭時 に癌が残存していた解剖学的部位は，上咽頭癌では， 遠隔葴器と原発巣にそれぞれ71,41\%と多く, 頸部りン 八節は29\%であった。中咽頭癌は100\%原発巣であった が, 転移は遠隔臓器, 頸部りンパ節それぞれ $27,18 \%$ と 多くなかった。下咽頭癌では原発巣, 遠隔葴器, 頸部 リンパ節いずれにも70，60，50\%と高率に腫崲が存在 していた，死因は全例原病死に分類されたが，5例の 合併症死，すなわち放射線性春䯣症による呼吸不全， 照射撚痕部位よりの出血死, 重篤な偽膜性大腸炎, 薬 郕性骨骵機能低下による敗血症および気管支炎が， そ れぞれ1例みられた。

これら5例を除いた原病死33例の死因を原病巣によ るものと, 頸部りンパ節または遠隔臓器への転移によ るものとに分けて検討した，上咽䫒癌では転移死が5?
\%とやや多い傾向にあり，中咽䫄癌では全例原発死に 上るものであつた。また下咽頭癌では転移死が $67 \%$ と 多く，その半分は頸部りンパ節転移による頸部動脈の 破絽によるものであった。転移蔵器は上咽䫒癌では肝, 肺，骨に多く，それぞれ69，59，53\%て，脾臓も24\% あった。中咽頭癌では $27 \%$ に肺転移を認めるのみであ り, 下咽頭癌では肺, 肝, 甲状腺にそれぞれ60，30, $20 \%$ みれたが，骨は10\%にすぎかつた。

結論 咽頭癌で死亡した38例の剖検所見を唡討し た.上咽頭癌では死因として遠隔転移死が多かった。 中咽頭癌では原発死が多く認められた。下咽頭癌では 遠隔転移死が多く，リンパ節転移による死亡も少なく な⿰力口。質問 丸山 毅(浦和市立)。中咽頭癌 の治療法の変化（抎大全摘）よって局所のコントロー ルは向上した。転移死のコントロールについて何か腫 湯学的に今後の示標となるべきものについて検索され ていれば教えて頂きたい。応答今回の中咽頭癌 症例の中には，拡大全摘施行例はない。㹡大全摘を施 行した症例には，死亡例は存在せず，局所のコントロ 一ルが向上したためにと考えられ，今後も積極的に㹡 大全摘を検討したいと考えている。

\section{4. 片側性扁桃腫大症例の臨床病理学的検討

\section{曾爾信行（駿河台日大）}

1975年3月〜1990年8月まで015年6力月に日本大 学病院耳鼻咽喉科外来受診し, 病理組織学的に悪性 疾患と診断された一側性扁桃腫大症例は57例であり， そのう方25例は悪性りンパ腫で, 癌腫は32例であった。 癌症例のうち 1 例は転移性扁桃腫痬であり，今回我々 は，䎐移性扁桃腫稕を除く原発性扁桃癌31例について の，主に治㙩成績について検討した。

TNM 及びStage 分類は1987年の UICCの分類を 用いた。 T3，T4の進展例は20例 (65\%) と多く，また 頸部リンパ節転移も25例 $(81 \%)$ と多くみられ，その
結果 Stage I, II の早期癌 3 例に対し, 大部分が Stage III, IV の進行癌であった。

Stage 別の5 年生存率はStage の進行と共に低下 し，全体では $47 \%$ \%すった、ステージIII, IVの扁平上 皮癌症例について初回の治療法别に5 年生存率を見る と, 放射線治療单独で伎 $50 \%$, 放射線治療上化学療法 の併用では $42 \%$ であった，対して放射線治療，化学療 法，頸部郭清術を併用したものは67\%，放射線治療， 化学療法，根治手術を併用したものは63\%とそれぞれ 比較的良好な 5 年生存率であった。局所の腫演形態を 